\title{
Kajian Pengembangan Kewirausahaan pada Kawasan Transmigrasi
}

\author{
Novita Wahyu Setyawati \\ Manajemen, Universitas Bhayangkara Jakarta Raya, Indonesia \\ Korespondensi penulis: novita.wahyu@dsn.ubharajaya.ac.id
}

\begin{abstract}
The development of entrepreneurship in transmigration areas is obstacles so that targets cannot be achieved effectively. This study aims to: (1) study the development of entrepreneurship implemented in the transmigration community; (2) reviewing the obstacles to developing entrepreneurship in transmigration areas; and (3) formulating efforts needed to increase entrepreneurship development in transmigration areas. The study was conducted with a qualitative approach with the type of descriptive research in the Musi Rawas area. The results of the study indicate that the development of entrepreneurship has increased capabilities and is beneficial for business development, but has not effectively increased entrepreneurship and business development capabilities. In general, the constraints of developing entrepreneurship are not focused, diffusion of knowledge, and skills are not effective, have not been connected with entrepreneurship development programs in other technical sectors/ units, and there has been no change in the way of thinking in formulating business development needs.
\end{abstract}

Keywords: Entrepreneurship development, transmigration area.

\begin{abstract}
Abstrak. Pengembangan kewirausahaan di kawasan transmigrasi kemungkinan dapat mengalami kendala, sehingga sasaran pengembangan tidak dapat tercapai secara efektif. Penelitian ini bertujuan untuk: (1) mengkaji pengembangan kewirausahaan yang diimplementasikan di kawassan transmigrasi, (2) mengkaji kendala pengembangan kewirausahaan di kawasan transmigrasi, dan (3) merumuskan upaya yang diperlukan untuk peningkatan pengembangan kewirausahaan di kawasan transmigrasi. Penelitian dilakukan dengan pendekatan kualitatif dengan jenis penelitian diskriptif pada kawasan Musi Rawas. Hasil penelitian menunjukkan bahwa pengembangan kewirausahaan telah meningkatkan kemampuan dan bermanfaat bagi pengembangan usaha, tetapi hal itu belum secara efektif meningkatkan kemampuan kewirausahaan dan pengembangan usahanya. Secara umum, kendala yang dijumpai dalam pengembangan kewirausahaan adalah tidak fokus, difusi pengetahuan, ketrampilan kurang efektif, belum terkoneksi dengan program pengembangan kewirausahaan pada sektor/unit teknis lainnya, dan belum adanya perubahan cara pikir dalam merumuskan kebutuhan pengembangan usaha.
\end{abstract}

Kata kunci: Pengembangan kewirausahaan, kawasan transmigrasi. 


\begin{tabular}{lr}
\hline Article Info: & \\
Received: December 10, $2018 \quad$ Accepted: March 23, 2019 & Available Online: April 11, 2019 \\
DOI: http://dx.doi.org/10.30588/jmp.v8i2.413 & \\
\hline
\end{tabular}

\section{PENDAHULUAN}

Pembangunan transmigrasi diharapkan mampu mengatasi kesenjangan antarkawasan dengan menciptakan pusat pertumbuhan baru yang dapat menggerakkan aktifitas perekonomian dan membuka ruang untuk berwirausaha. Terbukanya ruang berwirausaha tersebut diharapkan dapat meningkatkan pendapatan masyarakat yang dapat mendorong peningkatan daya saing daerah. Untuk melakukan aktifitas tersebut diperlukan wirausaha andal yang memiliki kompetensi dan semangat kewirausahaan. Untuk itu, para wirausahawan yang sudah memulai usahanya dan atau sudah memiliki minat menjadi wirausahawan di kawasan transmigrasi sangat membutuhkan dukungan pemerintah.

Menurut Georgopolous dan Tannembaum (1995), pada dasarnya pengembangan kewirausahaan di kawasan transmigrasi dimaksudkan untuk menumbuhkan kemampuan masyarakat dalam berwirausaha. Dengan kemampuan ini, para pelaku usaha diharapkan mampu menangkap peluang dan mengembangkan usahanya, sehingga perekonomian di kawasan transmigrasi dapat berkembang seperti yang diharapkan. Untuk mencapai tujuan tersebut, pelopor yang dapat mengembangkan wirausaha di kawasan permukiman transmigrasi diperlukan untuk menumbuhkan kader-kader pelopor wirausaha di kawasan tersebut, membentuk wadah himpunan wirausaha transmigrasi dan kelompok kewirausahaan transmigrasi sebagai sarana pembelajaran, mengakses program-program, dan konsultasi usaha.

Pada dasarnya, pengembangan kewirausahaan merupakan upaya untuk meningkatkan kemampuan kewirausahaan seseorang, sehingga mampu membuka usaha baru atau meningkatkan usaha yang sedang atau akan dikembangkan. Dalam konteks efektifitas, peningkatan kemampuan kewirausahaan seseorang merupakan pencapaian output, sedangkan kemampuan membuka usaha baru atau meningkatkan usaha yang sudah ada merupakan pencapaian outcome. Sebagaimana telah disebutkan di atas, efektivitas pengembangan kewirausahaan dalam penelitian ini dipahami sebagai keberhasilan program untuk meningkatkan kemampuan kewirausahaan seseorang, sehingga ia mampu membuka usaha baru atau meningkatkan usaha yang sudah ada. Dengan demikian, ia diharapkan mampu berwirausaha setelah memiliki kemampuan kewirausahaan.

Berdasarkan uraian tersebut di atas, penelitian ini bertujuan untuk: (1) mengkaji pengembangan kewirausahaan yang diimplementasikan di kawasan transmigrasi, (2) mengkaji kendala pengembangan kewirausahaan di kawasan transmigrasi, dan (3) merumuskan upaya yang diperlukan untuk peningkatan pengembangan kewirausahaan di kawasan transmigrasi.

\section{KAJIAN TEORITIS}

\section{Pengembangan Kewirausahaan}


Kata "entrepreneur" (entrepreneurship diterjemahkan menjadi kewirausahaan dalam tulisan ini, sedangkan entrepreneur diterjemahkan menjadi wirausahawan) berasal dari bahasa Perancis "entreprendre" yang berarti "melakukan" atau "melaksanakan." Wirausahawan adalah seseorang yang mengorganisasikan, mengelola, dan menanggung risiko sebuah usaha. Di samping itu, ada pendapat lain tentang beberapa karakteristik para usahawan yang berbeda dengan yang disebutkan di atas, di antaranya adalah (Yukl, 1996): (1) pada umumnya agresif, (2) memiliki semangat kompetisi yang tinggi, (3) perilakunya cenderung mengarah pada sasaran (goal-oriented), (4) percaya dirinya besar, (5) cenderung memanfaatkan peluang (oportunis), (6) tindakantindakannya biasanya mengandalkan intuisi, (7) bertindak sesuai kondisi nyata yang dijumpai di lapangan, (8) mampu belajar dari kesalahan, dan (9) mampu memanfaatkan ketrampilan membina hubungan sosial, dan sebagainya.

\section{Pentingnya Pengembangan Kewirausahaan}

Pengertian dan teori kewirausahaan tersebut penting dikaitkan dengan keadaan dan masalah yang dihadapi bangsa Indonesia saat ini dan masa mendatang dalam rangka mensukseskan tujuan nasional mencerdaskan dan mensejahterakan kehidupan bangsa. Saat ini, jumlah penduduk Indonesia melampaui angka 200 juta jiwa yang tersebar di lebih dari seribu pulau ini merupakan tantangan yang tidak kecil dan harus dihadapi secara tepat dan sistematis. Pentingnya pengembangan kewirausahaan dan pendidikan kewirausahaan bagi bangsa Indonesia dapat dijelaskan sebagai berikut (Pencari Ide Usaha, 2009):

1. Di awal abad ke-21, Indonesia telah menjadi negara terbesar kelima di dunia dilihat dari segi jumlah penduduk. Sebagian besar penduduknya adalah angkatan kerja dan sebagian dari jumlah itu adalah tenaga muda alumni perguruan tinggi. Jumlah penduduk yang besar tersebut bisa saja merupakan potensi apabila berkualitas baik, tetapi sebaliknya akan menambah beratnya beban pembangunan.

2. Menurut penelitian yang telah dilakukan, tampaknya ada korelasi antara jumlah penduduk yang berkewirausahaan dan tingkat kemakmuran suatu masyarakat. Negara maju memiliki wirausahawan lebih dari $6 \%$ jumlah penduduk, sedangkan jumlah wirausahawan Indonesia pada tahun 1982 belum mencapai 0,5\%.

3. Telah terbukti tingkat kemajuan dan keterbelakangan suatu negara tidak terletak pada jumlah penduduk, kekayaan alam, luas wilayah, warna kulit atau suku bangsa, atau usia kemerdekaan yang telah dialami, tetapi kemajuan atau keterbelakangan tersebut terletak pada kualitas manusianya.

\section{Kawasan Transmigrasi}

Transmigrasi (berasal dari bahasa Belanda yaitu transmigratie) adalah suatu program kerja pemerintah Indonesia untuk memindahkan penduduk dari suatu daerah yang padat penduduknya (kota) ke daerah lain (desa) di dalam wilayah Indonesia. Transmigrasi sebagai kegiatan perpindahan penduduk yang berorientasi pada pembangunan tidak terlepas dari masalah yang dihadapi oleh bangsa Indonesia secara keseluruhan. Ada pun masalah-masalah yang dihadapi tersebut di antaranya adalah kependudukan, pembangunan, dan sosial ekonomi masyarakatnya.

Berdasarkan Undang-Undang Republik Indonesia nomor 29 tahun 2009 tentang Ketransmigrasian (merupakan penyempurnaan dari Undang-Undang nomor 3 tahun 1972 tentang Pokok-pokok Transmigrasi), penyelenggaraan transmigrasi bertujuan 
untuk meningkatkan kesejahteraan transmigran dan masyarakat sekitarnya, pemerataan pembangunan daerah, dan memperkokoh persatuan dan kesatuan bangsa. Sesuai tujuan tersebut, maka transmigrasi masih sangat relevan di era otonomi daerah saat ini. Dengan demikian, masalah kependudukan adalah masalah yang sangat kompleks, sehingga penetapan ketentuan-ketentuan pelaksanaannya menjadi sangat penting. Dalam UndangUndang nomor 29 tahun 2009 tentang Ketentuan-ketentuan Pokok Transmigrasi disebutkan di dalam pasal 1 bahwa yang dimaksud dengan transmigrasi dan transmigran adalah:

1. Transmigrasi adalah perpindahan penduduk secara sukarela untuk meningkatkan kesejahteraan dan menetap di kawasan transmigrasi yang diselenggarakan oleh pemerintah.

2. Transmigran adalah warga negara Republik Indonesia yang berpindah secara sukarela ke kawasan transmigrasi.

Tujuan program transmigrasi terdiri atas dua hal, yaitu:

1. Untuk memberikan peluang berusaha dan kesempatan bekerja kepada anak bangsa secara terintegrasi dengan upaya pemberdayaan potensi sumber daya kawasan yang belum dimanfaatkan dan dikelola.

2. Untuk menciptakan kondisi yang mendorong terciptanya persatuan dan kesatuan bangsa sebagai pilar utama berdiri tegaknya negara kesatuan Republik Indonesia dalam jangka panjang.

\section{METODE PENELITIAN}

Analisis ini menggunakan pendekatan kuantitatif dan kualitatif dengan jenis penelitian eksplanatori dan memanfaatkan data primer dan sekunder. Teknik pengumpulan informasi dan pengenalan kebutuhan masyarakat menggunakan pendekatan partisipatori atau Participatory Rural Appraisal (PRA). Pendekatan tersebut melibatkan secara langsung dan partisipasi aktif masyarakat. Dalam kaitan tersebut, beberapa prinsip dasar yang harus diterapkan dalam pelaksanaan PRA yaitu melibatkan seluruh kelompok masyarakat yang menjadi representasi masyarakat desa secara umum dalam pengenalan potensi sumber daya setempat, memahami permasalahan yang dihadapi, mengidentifikasi jenis kebutuhan, dan merumuskan pentahapan kegiatan kelembagaan masyarakat di Kawasan Transmigrasi (KTM).

Pendekatan PRA (Participatory Rural Apraisal) ini digunakan untuk meningkatkan partisipasi masyarakat terutama dalam menyusun kebutuhan atau program. Metode pengumpulan data yang digunakan adalah:

1. Observasi (pengamatan) mendalam. Metode ini digunakan untuk mendapatkan data (informasi) tentang kondisi lokasi dan masyarakat melalui pengamatan secara mendalam terhadap situasi, kondisi kejadian (peristiwa) yang ada di lokasi permukiman, baik secara fisik lingkungan maupun sosial.

2. Wawancara mendalam (in-depth interview). Hal-hal yang tidak bisa dipahami melalui kegiatan pengamatan lapangan diperoleh melalui wawancara mendalam dengan masyarakat, baik tokoh-tokoh masyarakat maupun warga masyarakat pada umumnya.

3. Konseling yakni membantu menggali masalah dan potensi yang dimiliki, membuka alternatif-alternatif solusi dan mendorong masyarakat untuk mengambil keputusan berdasarkan pertimbangan yang bertanggungjawab. 
4. Pembelajaran yaitu alih pengetahuan/ketrampilan dan sistem nilai yang dimiliki oleh penyuluh melalui pertemuan-pertemuan dan praktik ketrampilan.

5. Konsultasi yaitu upaya memberikan jawaban, solusi, dan pemecahan masalah yang dibutuhkan oleh masyarakat transmigran.

\section{HASIL DAN PEMBAHASAN}

\section{Pengembangan Kewirausahaan}

Pengembangan kewirausahaan dapat ditelusuri melalui dua aspek, yaitu peningkatan kemampuan pelaku usaha dan pengembangan usahanya. Masyarakat di KTM Musi Rawas memiliki karakter yang berbeda, yaitu: kemampuan kewirausahaan yang masih terbatas, mengindikasikan belum inovatif, dan mengelola usaha secara tradisional sebagai usaha keluarga. Mereka umumnya memiliki perilaku manajerial yang masih terbatas dengan tidak adanya Rencana Anggaran Biaya (RAB), rencana usaha, dan laporan keuangan secara tertulis.

Proses pengembangan kewirausahaan belum secara efektif meningkatkan kemampuan kewirausahaan para masyarakatnya. Hal ini terlihat dari hasil wawancara dan diskusi dengan responden. Sebelum melakukan pengembangan kewirausahaan, rata-rata 90,8\% masyarakat belum mengetahui keempat indikator penilaian tersebut (Tabel 1). Sesudah pelaksanaan pengembangan kewirausahaan, jumlah masyarakat yang tidak mengetahui berkurang menjadi 63,3\%. Artinya, masih ada sekitar 63,3\% masyarakat yang belum meningkat pengetahuannya. Data selengkapnya dapat dilihat pada Tabel 1.

Hasil diskusi dengan masyarakat KTM Musi Rawas memperlihatkan bahwa pengembangan kewirausahaan belum secara efektif mampu meningkatkan kemampuan kewirausahaan sebagian besar masyarakat. Pelatihan pengembangan kewirausahaan sangat dirasakan manfaatnya oleh sebagian masyarakat. Pelatihan umumnya diikuti untuk menambah pengetahuan. Namun, tidak seluruh pengetahuan tersebut membuat para wirausaha menjadi trampil, karena tidak semua pengetahuan dipraktikkan dalam pengembangan usaha. Selain itu, pengetahuan atau ketrampilan yang dimiliki oleh sebagian masyarakat cenderung tidak meningkat.

\section{Kendala Pengembangan Kewirausahaan}

Berbagai aktifitas yang dilakukan dalam proses pengembangan kewirausahaan dimaksudkan agar memberikan manfaat bagi pengembangan usaha. Manfaat tersebut antara lain, sebagai sarana pembelajaran untuk meningkatkan kompetensi sesuai kebutuhan, kemudahan mengakses modal/sarana usaha, dan peningkatan jejaring kerjasama. Hasil wawancara dan diskusi di KTM Musi Rawas menyimpulkan bahwa kendala pengembangan kewirausahaan teridentifikasi sebagai berikut:

1. Kegiatan yang dilakukan oleh pendamping dan masyarakat dalam transfer pengetahuan belum terjadi.

2. Pendamping tidak/belum memiliki kompetensi sebagai pendamping. Demikian pula, pendamping belum memiliki kompetensi sebagai motivator.

3. Pada umumnya, motivasi masyarakat KTM Musi Rawas mengikuti program pengembangan adalah untuk mendapatkan bantuan berupa modal, peralatan dan sarana usaha. Belum ada perubahan mindset dalam merumuskan kebutuhan pengembangan usaha. 
4. KTM Musi Rawas belum efektif sebagai wadah membangun kerjasama usaha dan meningkatkan kemampuan kewirausahaan karena berbasis desa.

5. Pengembangan kewirausahaan belum terkoneksi dengan kegiatan sektor-sektor lainnya, sehingga program tersebut tidak memperoleh dukungan program/kegiatan dari sektor lainnya.

Tabel 1. Pengembangan Kewirausahaan bagi Peningkatan Kemampuan Wirausaha di Kawasan KTM Musi Rawas

\begin{tabular}{|c|c|c|c|}
\hline No & Indikator Efektivitas & $\begin{array}{l}\text { Sebelum } \\
(\%)\end{array}$ & $\begin{array}{l}\text { Sesudah } \\
(\%)\end{array}$ \\
\hline \multirow[t]{6}{*}{1} & $\begin{array}{l}\text { Inovasi (pengetahuan tentang peningkatan kualitas atau variasi } \\
\text { usaha }\end{array}$ & & \\
\hline & Tidak Tahu & 90,0 & 63,3 \\
\hline & Tahu $*$ & 6,7 & 6,7 \\
\hline & Bisa ** & 3,3 & 13,3 \\
\hline & Terampil *** & 0,0 & 16,7 \\
\hline & Ahli & 0,0 & 0,0 \\
\hline \multirow[t]{6}{*}{2} & $\begin{array}{l}\text { Keberanian mengambil resiko (pengetahuan tentang strategi } \\
\text { mengembangkan usaha baru atau yang sudah ada) }\end{array}$ & & \\
\hline & Tidak Tahu & 90,0 & 70,0 \\
\hline & Tahu $*$ & 6,7 & 3,3 \\
\hline & Bisa $* *$ & 0,0 & 13,3 \\
\hline & Terampil *** & 0,0 & 13,3 \\
\hline & Ahli & 0,0 & 0,0 \\
\hline \multirow[t]{6}{*}{3} & Tanggung jawab (pembuatan RAB atau pembukuan) & & \\
\hline & Tidak Tahu & 93,3 & 70,0 \\
\hline & Tahu $*$ & 6,7 & 13,3 \\
\hline & Bisa ** & 0,0 & 10,0 \\
\hline & Terampil *** & 0,0 & 6,7 \\
\hline & Ahli & 0,0 & 0,0 \\
\hline \multirow[t]{12}{*}{4} & $\begin{array}{l}\text { Perilaku manajerial (pembuatan rencana usaha dan } \\
\text { pengembangan jejaring usaha) }\end{array}$ & & \\
\hline & Tidak Tahu & 90,0 & 70,0 \\
\hline & Tahu $*$ & 6,7 & 13,3 \\
\hline & Bisa ** & 3,3 & 6,7 \\
\hline & Terampil *** & 0,0 & 10,0 \\
\hline & Ahli & 0,0 & 0,0 \\
\hline & Rata-Rata & & \\
\hline & Tidak Tahu & 90,8 & 68,3 \\
\hline & Tahu $*$ & 6,7 & 9,2 \\
\hline & Bisa $* *$ & 2,5 & 10,8 \\
\hline & Terampil $* * *$ & 0,0 & 11,7 \\
\hline & Ahli & 0,0 & 0,0 \\
\hline
\end{tabular}

Keterangan: * Sampai pada taraf mengetahui.

** pengetahuan pernah diimplementasikan/dipraktikkan dan bias.

*** diimplementasikan secara regular dalam pengembangan usaha.

\section{Upaya Peningkatan Pengembangan Kewirausahaan}

Berdasarkan kendala-kendala pengembangan kewirausahaan di KTM Musi Rawas, rekomendasi peningkatan pengembangan kewirausahaan sebagai berikut:

1. Kelompok wirausaha sebaiknya dibentuk sesuai komoditas dan fokus pada usahanya. Misalnya, kelompok bengkel, kelompok pedagang warung, kelompok peda- 
gang sayur, industri rumah tangga, dan sebagainya. Hal ini dimaksudkan untuk memmudahkan upaya menjalin kemitraan dan lebih fokus dan termotivasi untuk saling belajar dan bertukar pendapat, sehingga mampu meningkatkan pengetahuan dan ketrampilannya.

2. Mengacu pada upaya nomor 1 di atas, mediasi program sektoral dan atau mitra usaha perlu dilakukan, atau melalui lembaga lainnya. Misalnya, kelompok pedagang warung dimediasi oleh Dinas Perindustrian, Perdagangan, dan Koperasi dan mitra usaha.

3. Pendamping program sebaiknya dipilih dari mereka yang memiliki kompetensi sebagai motivator, fasilitator, maupun mediator.

4. Kejelasan setiap peran pendamping sangat diperlukan, karena peran pendamping dapat menumbuhkan motivasi dan kesadaran anggotanya, bukan semata-mata memperoleh bantuan saja.

5. Sebaiknya, calon wirausaha mengikuti program pelatihan teknis sesuai dengan jenis usahanya, karena tidak semua pendamping program memiliki kemampuan teknis di segala bidang usaha.

\section{KESIMPULAN DAN SARAN}

\section{Kesimpulan}

Berdasarkan hasil pembahasan tersebut di atas, maka dapat disimpulkan bahwa kendala pengembangan kewirausahaan di KTM Musi Rawas adalah:

1. Kelembagaan yang dibangun kurang fokus karena masih berbasis desa.

2. Pengembangan kewirausahaan tidak terkoneksi dengan program pengembangan kewirausahaan pada sektor/unit teknis lainnya.

3. Pelatihan belum sesuai dengan kebutuhan dan jenis usahanya.

4. Kurangnya motivasi dan kesadaran kritis untuk mengubah pola pikir pelaku usaha dalam merumuskan kebutuhan pengembangan usaha, pengembangan kelembagaan, pelatihan teknis, dan manajemen.

\section{Saran}

Untuk meningkatkan pengembangan kewirausahaan di kawasan transmigrasi sebagai upaya sumber pendapatan keluarga, maka yang perlu dilakukan adalah:

1. Pengembangan kewirausahaan dilaksanakan secara terpadu dengan program pengembangan usaha dan program pengembangan kewirausahaan pada sektor lainnya.

2. Pengembangan kewirausahaan dilakukan dengan pendekatan kelembagaan dan fokus pada sektor usahanya, sehingga kegiatan pelatihan dapat disesuaikan dengan jenis usahanya.

3. Fasilitasi pemerintah yang dilakukan terdiri atas fasilitasi penumbuhan motivasi dan kesadaran kritis untuk mengubah pola pikir pelaku usaha dalam merumuskan kebutuhan pengembangan usaha, pengembangan kelembagaan, pelatihan teknis, dan manajemen.

4. Pendamping atau pelatih harus memiliki kompetensi dan bersedia tinggal di lokasi dalam periode waktu tertentu, sehingga ia mampu membangkitkan motivasi dan kesadaran kritis bagi para pelaku usaha. 


\section{DAFTAR REFERENSI}

Bhandari, B. B. (2003). Participatory Rural Appraisal. In: Kanagawa, Japan: Institute for Global Environmental Strategies (IGES), p. Module 4.

Direktorat Jenderal Pembinaan Pengembangan Masyarakat dan Kawasan Transmigrasi (2006). Jakarta: Kota Terpadu Mandiri.

Direktorat Jenderal P2MKT (2013). Laporan Perkembangan Penumbuhan dan Pengembangan Kewirausahaan di Permukiman Transmigrasi/Kawasan Transmigrasi. Edisi November.

Georgopolous \& Tannembaum (1995). Efektivitas Organisasi. Jakarta: Erlangga.

Kuswanto, dkk. (2002). Pengertian Transmigrasi dan Tujuan Transmigrasi. Solo: PT. Tiga Serangkai Pustaka.

Keputusan Menteri Tenaga Kerja dan Transmigrasi RI Nomor: Kep. 214/Men/V/2007 tentang Pedoman Umum Pembangunan Kota Terpadu Mandiri.

Najiyati, S. dkk. (2005). Pemberdayaan Masyarakat Lahan Gambut. Bogor: Wetlands Internasional-Indonesian Program.

Najiyati, S. dkk. (2013). Model Pelatihan Efektif Mendukung Pengembangan Usaha Di Kawasan Transmigrasi. Jakarta: Puslitbang Ketransmigrasian.

Pencari Ide Usaha (2009). Pentingnya Pengembangan Kewirausahaan dan Pendidikan Kewirausahaan bagi Bangsa Indonesia. 22 Januari. https://otakusaha.wordpress. com/09/01/22/pentingnya-pengembangan-kewirausahaa-dan-pendidikan-kewirausahaan-bagi-bangsa-indonesia/

Sarwono, J. (2006). Metode Penelitian Kuantitatif \& Kualitatif. Yogyakarta: Penerbit Graha Ilmu.

Sasongko, A. (2014). Perubahan Sosial dan Budaya Petani Sawit (Studi Deskriptif DesaTransmigran Batang Pane-I, Kec. Padang Bolak, Kab. Padang Lawas Utara, Prov.Sumatera Utara). Skripsi. Tidak diterbitkan. Universitas Sumatera Utara.

Setiadi, E. M. dkk. (2012). Ilmu Sosial dan Budaya Dasar. Jakarta: Kencana.

Sugiyono (2013). Metode Penelitian Kuantitatif, Kualitatif dan R\&D. Bandung: Alfabeta.

Undang-Undang Nomor 15 Tahun 1997 tentang Ketransmigrasian sebagaimana telah diubah dengan Undang-Undang Nomor 29 Tahun 2009 tentang Perubahan Atas Undang-Undang Nomor 15 Tahun 1997 tentang Ketransmigrasian.

Yukl, G. (1996). Kepemimpinan Dalam Kewirausahaan. Prerhallindo.

Yumi dkk. (2011). Model Pengembangan Pembelajaran Petani Dalam Pengelolaan Hutan Rakyat Lestari: Kasus di Kabupaten Gunung Kidul, Provinsi DIY dan Wonogiri, Prov. Jawa Tengah. Pengembangan Penyuluhan Kehutanan, Badan Penyuluhan dan Pengembangan SDM Kehutanan. 